Journal of Animal and Veterinary Advances 11 (8): 1223-1229, 2012

ISSN: $1680-5593$

(C) Medwell Journals, 2012

\title{
Effects of Glucose on Differentiation and Fat Metabolism of Chicken Preadipocytes
}

\author{
Qi Renli, Sun Chao, Yan Jun, Yang Haili, Zhao Taotao and Zhao Xia \\ College of Animal Science, Northwest A\&F University, 712100 Yangling, China
}

\begin{abstract}
The present study was carried out to illustrate the effect of glucose on chicken (Gallus gallus) preadipocyte differentiation and fat metabolism. Adipocyte differentiation was initiated by maintaining confluent cells in a glucose-free medium supplemented with different concentrations of glucose. Upon exposure to high concentrations of glucose $\left(25 \mathrm{mmol} \mathrm{L}^{-1}\right)$, Peroxisome Proliferator-Activated Receptor $\gamma$ (PPAR $\left.\gamma\right)$ and $\mathrm{CCAAT} /$ Enhancer-Binding Protein $\alpha(\mathrm{C} / \mathrm{EBP} \alpha)$ as adipocyte differentiation markers were significantly increased compared with control cells. The morphology of the glucose-treated cells changed from fibroblast-like to polygonal and cells treated with moderate concentrations of glucose $\left(15 \mathrm{mmol} \mathrm{L}^{-1}\right)$ accumulated the most number of cytoplasmic lipid droplets as estimated by Oil red O staining. Compared with control cells varying concentrations of glucose affected the mRNA expression and protein levels for Fatty Acid Synthesis (FAS) and Adipose Triglyceride Lipase (ATGL), the master regulators of fat metabolism. Moreover, the mRNA expression levels and protein contents of fatty acid transporters in glucose-treated cells were higher than in untreated cells. These results indicated that glucose is essential material for chick adipocytes differentiation. Moreover, overhigh concentrations of glucose maybe stimulate lipolysis in the cells.
\end{abstract}

Key words: Glucose, chicken, preadipocyte, fat metabolism, cell differentiation, fatty acid transporter

\section{INTRODUCTION}

Adipose tissue is an important energy store in animal providing fuels to other organs. White adipose tissue has endocrine functions and secretes important protein factors such as adiponectin and leptin (Renaldi et al., 2009; Zhang et al., 1994). As such the normal growth and function of adipocytes are necessary for animal health and reproduction. Preadipocytes are transformed from multipotential stem cell or embryonic stem cell (Poulos et al., 2010).

These shuttle-type cells are smaller than adipocytes and have no fat droplets in their cytoplasm (Brun et al., 1996; Lee et al., 2011; Yuan and Zhao, 2011). Preadipocytes can proliferate and differentiate into mature adipocytes depending on their energy balance and functions. Several transcription regulatory factors have been found to regulate the proliferation and differentiation of preadipocytes, some of which include Peroxisome Proliferators-Activated Receptor $\gamma$ (PPAR $\gamma$ ) and CCAAT/Enhancer-Binding Protein $\alpha(\mathrm{C} / \mathrm{EBP} \alpha)$ (Brun et al., 1996; Fernyhough et al., 2007; Tanaka et al., 1997; Lee et al., 2011; Yuan and Zhao, 2011). However, relatively few studies have attempted to culture preadipocytes from chickens and details of chicken preadipocyte differentiation and fat metabolism remain incompletely understood.
Some experiments have suggested that different levels of energy intake exert significant effects on fat metabolism and accumulation in animals (Qiao et al., 2011; Richards et al., 2003). However, few related studies on cell have been published. Glucose is an important energy source for animals. Thus, the current study attempts to illustrate the effects of glucose in medium (as an energy source) on the differentiation and fat metabolism of chicken preadipocytes.

\section{MATERIALS AND METHODS}

Cell culture: Male chicks (Gallus gallus, Avian strain) were obtained from a commercial hatchery. The abdominal adipose tissues of 7 days old chicks were excised by sterile dissection following ethical rapid decapitation. Adipose tissue was extensively washed with PBS supplemented with high concentrations of mycillin and cut into small pieces in Dulbecco's Modified Eagle's Medium (DMEM, pH 7.4; Invitrogen, USA). After the adipose tissue was digested with collagenase I (Invitrogen, USA) at $37^{\circ} \mathrm{C}$ for $45 \mathrm{~min}$, the cell suspension was filtered through a $200 \mu \mathrm{m}$ nylon mesh to remove undigested tissue debris.

The filtered cells were extensively washed thrice by centrifugation at $1200 \mathrm{r} \mathrm{m}^{-1}$ for $5 \mathrm{~min}$ and cells were collected as pellets from the test tube. The cells were resuspended in fresh DMEM/F12 containing $10 \%(\mathrm{v} / \mathrm{v})$

Corresponding Author: Sun Chao, College of Animal Science, Northwest A\&F University, 712100 Yangling, China 
fetal calf serum (Gibco, USA), $100 \mathrm{IU} \mathrm{mL}^{-1}$ penicillin and $80 \mathrm{U} \mathrm{mL}^{-1}$ streptomycin in a new test tube. The cells were seeded on $35 \mathrm{~mm}$ primary culture dishes at a density of $8 \times 10^{4}$ cells $/$ dish and cultured at $37^{\circ} \mathrm{C}$ under a humidified atmosphere of $5 \% \mathrm{CO}_{2}$ and $95 \%$ air until confluence.

Cell treatment: The cells were divided into 4 groups: high glucose group (glucose-free medium $+25 \mathrm{mmol} \mathrm{L}^{-1}$ glucose, $25 \mathrm{mM}$ group), moderate glucose group (glucose-free medium $+15 \mathrm{mmol} \mathrm{L}^{-1}$ glucose, $15 \mathrm{mM}$ group), low glucose group (glucose-free medium + $5 \mathrm{mmol} \mathrm{L}{ }^{-1}$ glucose, $5 \mathrm{mM}$ group) and control group (glucose-free medium, C group).

Triglyceride (TG) assay: Cytoplasmic lipid droplets were determined by Oil red $\mathrm{O}$ staining (Invitrogen, USA) as described previously (Sun et al., 2011a). Briefly, the cells were washed three times in PBS and then fixed in 10\% $(\mathrm{v} / \mathrm{v})$ formaldehyde for $30 \mathrm{~min}$. The fixed cells were washed three times in PBS and stained with a working solution of $\mathrm{Oil}$ red $\mathrm{O}$ for $30 \mathrm{~min}$ at room temperature. The cells were then washed with deionized water and extracted by $100 \%$ avantin for colorimetric analysis at $510 \mathrm{~nm}$. Concentrations of triglyceride in cells were tested using Triglyceride kit (Biosino Bio-Technology and Science Inc., China).

RNA extraction and real-time PCR: The mRNA expression of key factors for fat metabolism (FAS and ATGL), sign factors for cell differentiation ( $\mathrm{C} / \mathrm{EBP} \alpha$ and PPAR $\gamma$ ) and Fatty Acids Transporters (FATP1, FABP and FAT) were measured by using real-time RCR as described previously (Sun et al., 2011b). Total RNA was extracted from the cells using RNAiso Plus kits (TaKaRa, Japan) according to the manufacturer's instructions. Reverse transcription was performed for first-strand cDNA synthesis by using the Primescript RT reagent kit
(TaKaRa, Japan). Real-time PCR was performed with an iQ5 system (BioRad, USA) using a $20 \mu \mathrm{L}$ reaction mixture containing $12.5 \mu \mathrm{L}$ SYBR Premix Ex Taq ${ }^{\mathrm{TM}}$ II (TaKaRa, Japan), $1 \mu \mathrm{L}$ Forward primer, $1 \mu \mathrm{L}$ Reverse primer, $2 \mu \mathrm{L}$ template cDNA and $8.5 \mu \mathrm{L} \mathrm{ddH}_{2} \mathrm{O}$. The cycling conditions consisted of an initial, single cycle for $30 \mathrm{sec}$ at $95^{\circ} \mathrm{C}$ followed by 40 cycles of $5 \mathrm{sec}$ at $95^{\circ} \mathrm{C}$ and $35 \mathrm{sec}$ at Tm (Table 1). To correct the differences in the amounts of template DNA, the expression data were shown as a ratio to $\beta$-actin and $18 \mathrm{~S}$ rRNA which was used an internal control. The expression of genes was analyzed by using $2^{-\Delta \Delta \mathrm{Ct}}$ Methods.

Western blotting analysis: Whole cell extracts were prepared using $150 \mu \mathrm{L} / 35 \mathrm{~mm}$ dish lysis buffer for $30 \mathrm{~min}$ at $4^{\circ} \mathrm{C}$. The buffer contained $50 \mathrm{mM}$ Tris ( $\left.\mathrm{pH} 7.4\right), 150 \mathrm{mM}$ $\mathrm{NaCl}, 1 \% \mathrm{NP}-40$ and $0.1 \% \mathrm{SDS}$. After centrifugation at $12,000 \mathrm{~g}$ for $10 \mathrm{~min}$ at $4^{\circ} \mathrm{C}$, the supernatants were removed and their protein concentrations were determined by the bicinchoninic acid method using bovine serum albumin as the standard.

Total protein extracts were separated by $12 \%$ SDSPAGE and transferred to polyvinylidene membranes ( $60 \mathrm{~V}$ for $4 \mathrm{~h}$ ). The membranes were blocked with 5\% nonfat milk in TBST (Tris Buffered Saline containing 0.1\% Tween 20) at room temperature for $2 \mathrm{~h}$ and probed overnight with primary antibodies at $4^{\circ} \mathrm{C}$ (anti-PPAR $\gamma, 1: 250$; anti-ATGL, 1:400; anti-FAS, 1:300 and anti- $\alpha$-actin, 1:500. Santa Cruz, USA). After washing with TBST, the membranes were probed with a horseradish peroxidase-labeled secondary antibody (1:10000, Santa Cruz, USA) at room temperature for $1.5 \mathrm{~h}$. Blots were visualized with chemiluminescence reagent (Millipore, USA) using an imaging system (BioRad, USA).

Enzyme-Linked Immunosorbent Assay (ELISA): The cells were collected for glucose treatment $96 \mathrm{~h}$ and crushed by ultrasonication $(28 \mathrm{kHz}, 30 \mathrm{~min})$. The levels of fatty acid

\begin{tabular}{|c|c|c|c|}
\hline Genes & Primer sequences $\left(5^{\prime} \rightarrow 3^{\prime}\right)$ & Gene ID & Temperature $\left({ }^{\circ} \mathrm{C}\right)$ \\
\hline \multirow[t]{2}{*}{$\overline{\beta-a c t i n}$} & F: ACCACAGCCGAGAGAGAAAT & & \\
\hline & R: GACCTGACCATCAGGGAGTT & NM_205518 & 58.0 \\
\hline \multirow[t]{2}{*}{$18 S$ rRNA } & F:GTATGGTGGCAAAGCTGAAACTTA & & \\
\hline & R:AAGAGCTCTCAATCTGTCAATCCT & AF173612 & 58.5 \\
\hline \multirow[t]{2}{*}{$F A S$} & F: AAGGAGGAAGTCAACGGG & & \\
\hline & R: GATGGTGAGGAGTCGGAT & NM_205155.2 & 53.5 \\
\hline \multirow{2}{*}{$A T G L$} & F: TGGAACTGTCTCGTGGG & & \\
\hline & R: CTACTGTGGGCTGATACCT & EU_240627.2 & 50.5 \\
\hline \multirow[t]{2}{*}{$P P A R \gamma$} & F: ACCACTCGCATTCCTTTGAC & & \\
\hline & R: CCACAGACTCGGCACTCAAT & NM_001001460 & 60.2 \\
\hline \multirow[t]{2}{*}{$C / E B P \alpha$} & F:GGTGGACAAGCAAGAACAGCA & & \\
\hline & R: GATCTGGAGACCCGAAACCA & NM_001031459.1 & 59.1 \\
\hline \multirow[t]{2}{*}{$F A T P-1$} & F: CGGTGCTGTTACGAGTGA & & \\
\hline & R: CACGGCGTTGGAATACTT & NM_001039602 & 61.5 \\
\hline \multirow[t]{2}{*}{$F A B P$} & F: ATGTGCGACCAGTTTGTG & & \\
\hline & R: TTTGCCATCCCACTTCTG & NM_204290 & 50.8 \\
\hline \multirow[t]{2}{*}{ FAT } & F: CTGGGAAGGTTACTGCGATTT & & \\
\hline & R: TTCACGGTCTTACTGGTCTGG & DQ323177 & 52.9 \\
\hline
\end{tabular}


transporters (FATP1, FABP and FAT) in the cell lysate were determined using commercial ELISA kits ( $R$ and $D$ Systems, USA).

Statistical analyses: The SPSS 13.0 Statistics Software Package was used for one-way ANOVA and t-tests. Data were presented as means $\pm \mathrm{SE}$ and differences were considered statistically significantly at $\mathrm{p}<0.05$ or $\mathrm{p}<0.01$.

\section{RESULTS}

Morphological changes in chicken preadipocytes: Different glucose concentrations markedly affected the morphology of chicken preadipocytes. Figure 1 shows that compared with control group, the numbers of mature adipocytes significantly increased in both the 15 and $25 \mathrm{mM}$ groups after $72 \mathrm{~h}$. No significant difference was observed between the $5 \mathrm{mM}$ group and the control group. The number of dead cells was also found to have significantly increased in the $25 \mathrm{mM}$ group. Intracellular lipid droplets were observed by $\mathrm{Oil}$ red $\mathrm{O}$ staining with the most number of droplets found in the $15 \mathrm{mM}$ glucose group.

Detection TG levels in chicken preadipocytes: Figure 2 shows the effects of glucose on lipid accumulation in chicken preadipocytes. Compared with the control group, a significant increase in I ntracellular TG content in the $15 \mathrm{mM}$ and $25 \mathrm{mM}$ glucose groups ( $<<0.01$ ) was observed.

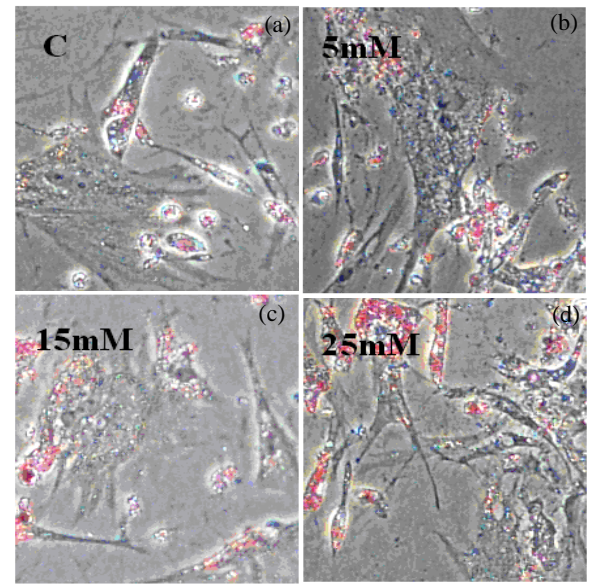

Fig. 1: Morphological changes in chicken preadipocytes under different glucose concentrations. Photomicrographs of Oil red $\mathrm{O}$ staining show cells treated with $0,5,15$ and $25 \mathrm{mmol} \mathrm{L}^{-1}$ glucose (20x magnification). The number of mature adipocytes significantly increased in the 15 and $25 \mathrm{mM}$ glucose groups compared with the control group (no glucose); a) Control; b) $5 \mathrm{mM}$; c) $5 \mathrm{mM}$ and d) $25 \mathrm{mM}$
mRNA expression and protein level of cell differentiation factors: PPAR $\gamma$ and $\mathrm{C} / \mathrm{EBP} \alpha$ are two sign factors for adipocyte differentiation. Data based on real-time PCR and Western blot analysis indicted that the mRNA expression and protein levels of PPAR $\gamma$ significantly increased in glucose-treated cells compared with control cells with increasing glucose concentrations, the mRNA expression and protein levels of PPAR $y$ increased in glucose-treated cells (Fig. $3 \mathrm{~b}$ and d). $\mathrm{C} / \mathrm{EBP} \alpha$ showed higher expression levels in the 15 and $25 \mathrm{mM}$ groups compared with the control group and no difference was observed between the $5 \mathrm{mM}$ and control groups (Fig. 3a and c).

mRNA expression and protein level of fat metabolism factors: The current study found that the mRNA expression and protein levels of fat metabolism regulators were significantly changed in glucose-treated chicken preadipocytes (Fig. 4).

Compared with the control group, increasing concentrations of glucose increased the mRNA expression and protein level of FAS which is a key factor for FA synthesis and fat accumulation in cells. ATGL is a key factor for TG hydrolysis. Data showed that the expression level of ATGL significantly increased only in the $25 \mathrm{mM}$ group and no differences were observed between the control 5 and $15 \mathrm{mM}$ groups.

mRNA expression and protein contents of Free Fatty Acids (FFAs) transporters: It was initially believed that FFAs enter cells merely by diffusion through the phospholipid bilayers. However, increasing evidence has shown that aside from this diffusion component, the intestine, liver, heart, adipose tissue and other organs also possess a saturable and complete FA transport system

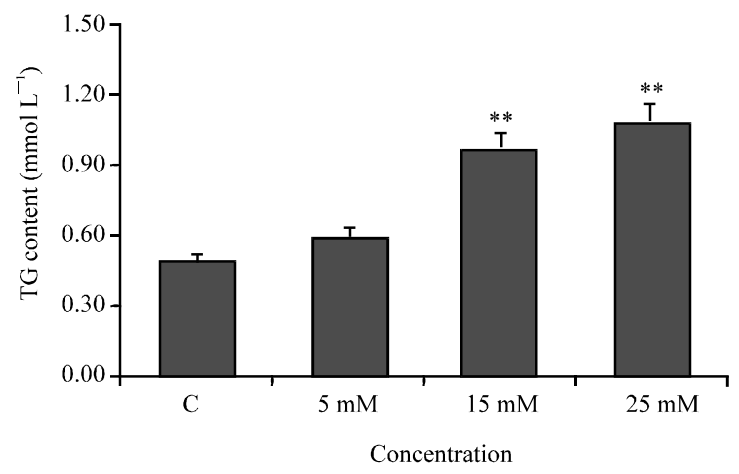

Fig. 2: Effects of glucose on the TG content in chicken preadipocytes. Compared with the control group, ** means $\mathrm{p}<0.01$ 

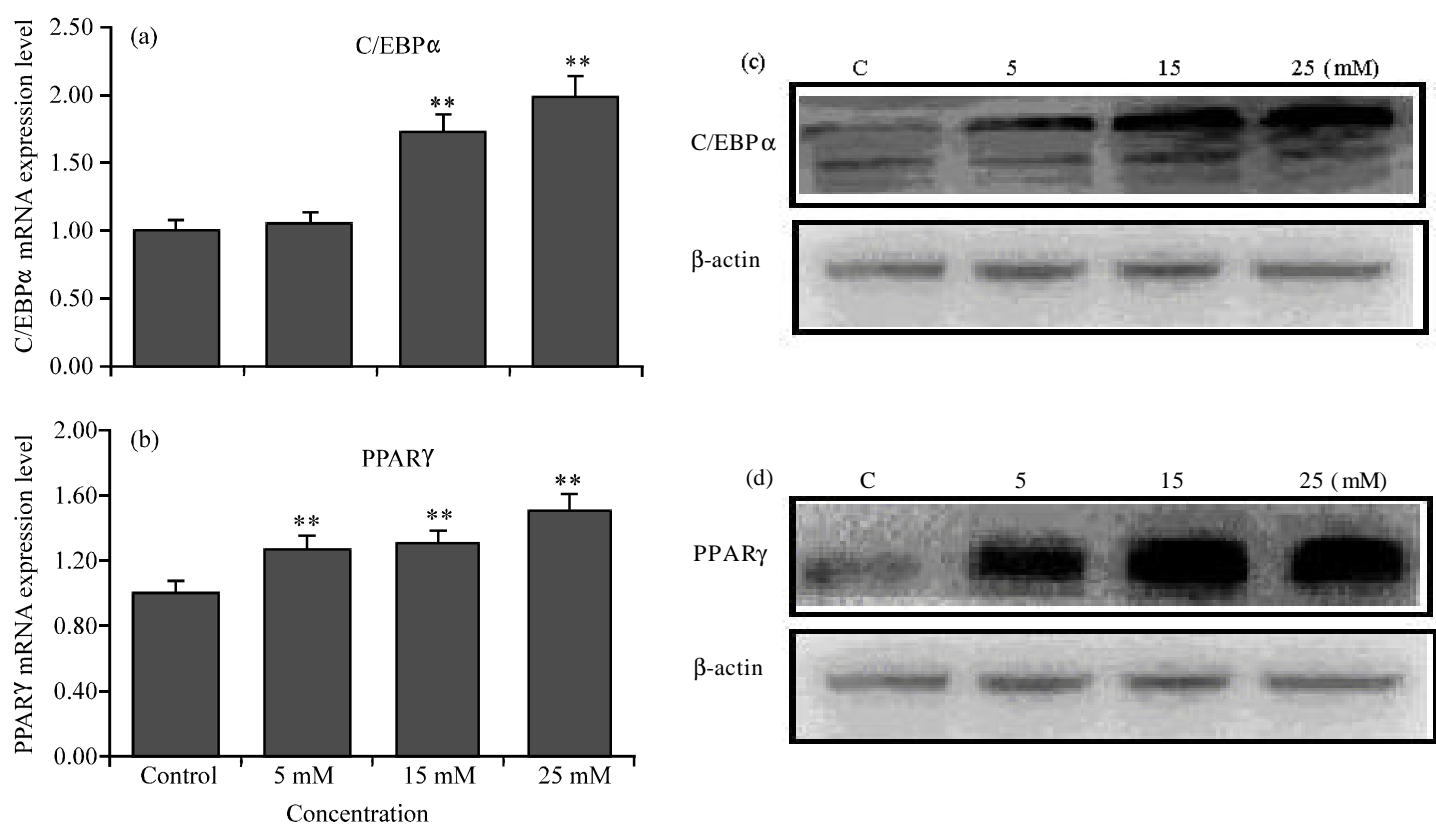

Fig. 3: Effects of glucose on the expression of cell differentiation factors; a) mRNA expression of C/EBP $\alpha$; b) mRNA expression of PPAR $\gamma ; \mathrm{c}$ ) Protein level of $\mathrm{C} / \mathrm{EBP} \alpha$; d) Protein level of PPAR $\gamma$ mRNA expressions of genes were detected using qRT-PCR and the protein contents were measured by Western blot analysis. Compared with the control group, ${ }^{* *}$ means $\mathrm{p}<0.01$
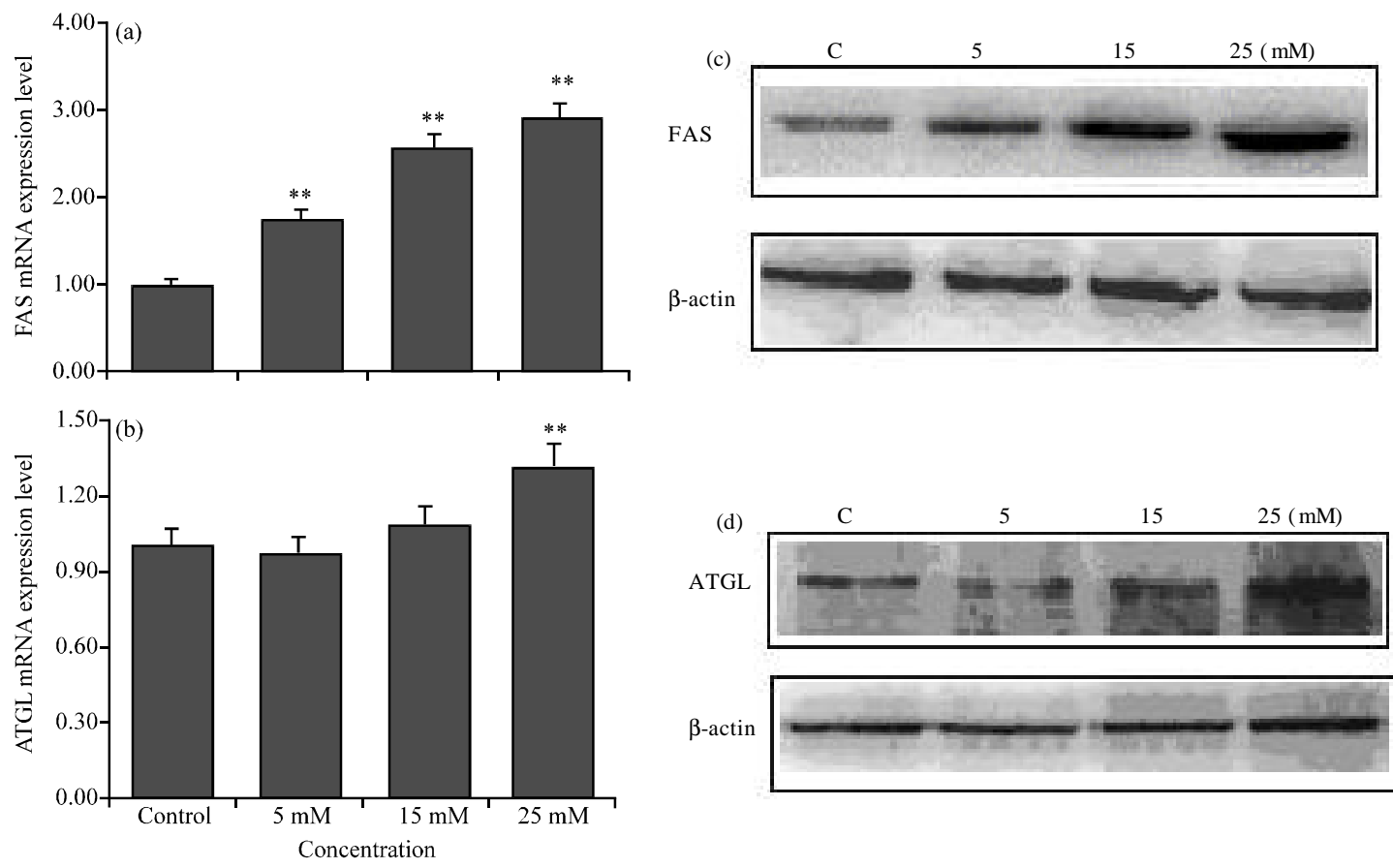

$\beta$-actin

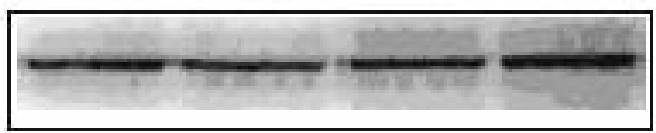

Fig. 4: Effects of glucose on the expression of the fat metabolism factors; a) mRNA expression of FAS; b) mRNA expression of ATGL; c) Protein level of FAS; d) Protein level of ATGL. mRNA expressions of genes were detected using qRT-PCR and the protein contents were measured by Western blot analysis. Compared with the control group, ${ }^{* *}$ means $\mathrm{p}<0.01$ 
Table 2: Effect of glucose on FA transporter contents in chicken preadipocytes

\begin{tabular}{|c|c|c|c|c|}
\hline Contents & $5 \mathrm{mM}$ group & $15 \mathrm{mM}$ group & $25 \mathrm{mM}$ group & Control group \\
\hline FATP1 (ug L L $)^{-1}$ & $1.59 \pm 0.17^{\mathrm{C}}$ & $8.53 \pm 0.31^{\mathrm{B}}$ & $13.24 \pm 0.24^{\mathrm{A}}$ & $1.11 \pm 0.20^{\mathrm{D}}$ \\
\hline FABP (ng L $\left.{ }^{-1}\right)$ & $49.41 \pm 2.25^{\mathrm{C}}$ & $365.33 \pm 3.37^{\mathrm{A}}$ & $210.33 \pm 2.96^{\mathrm{B}}$ & $36.59 \pm 1.61^{\mathrm{D}}$ \\
\hline FAT $\left(\mathrm{UL}^{-1}\right)$ & $9.14 \pm 0.49^{C}$ & $29.98 \pm 0.35^{\mathrm{B}}$ & $55.71 \pm 0.65^{\AA}$ & $6.93 \pm 0.58^{\mathrm{D}}$ \\
\hline
\end{tabular}

Data are expressed as the mean $\pm \mathrm{SE}, \mathrm{n}=8$; In the same row, means with different letters are significantly different $(\mathrm{p}<0.05)$, means with same letters are not significantly different $(\mathrm{p}>0.05)$
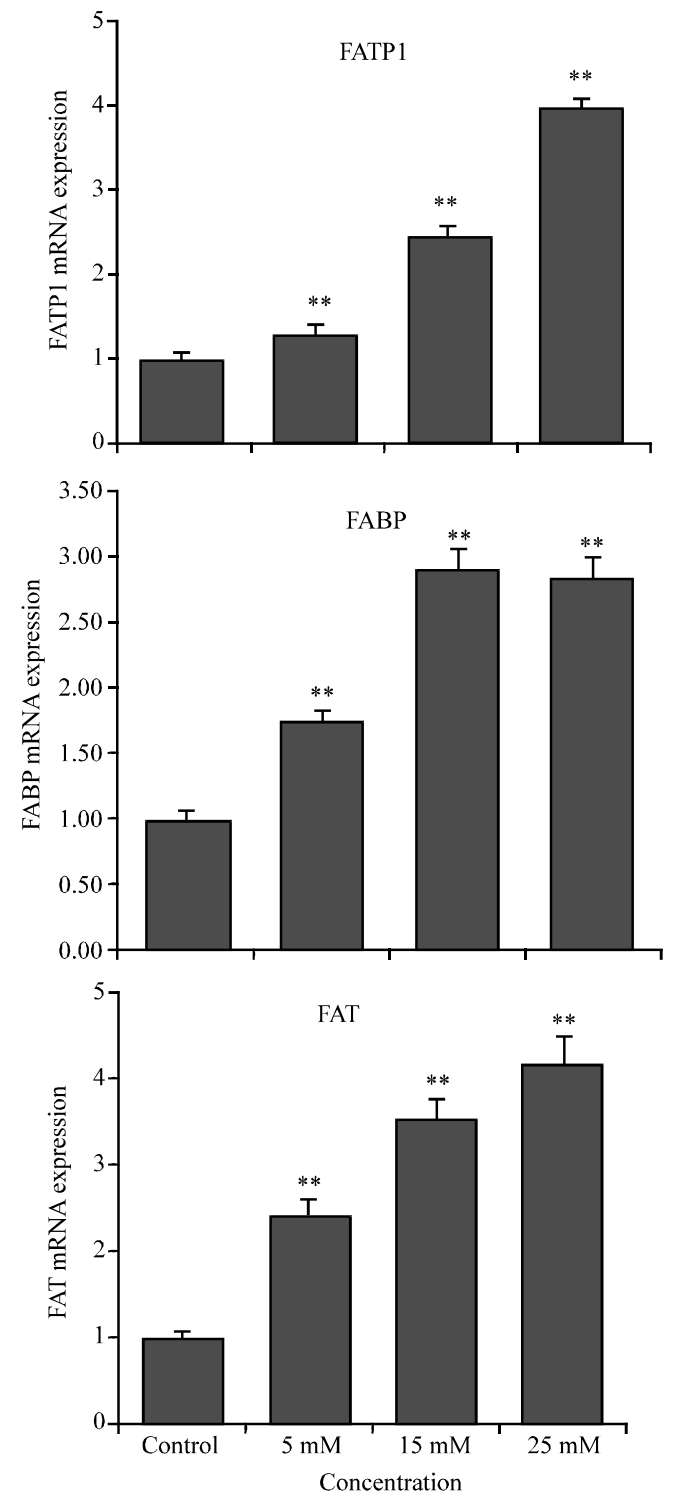

Fig. 5: Effects of glucose on the mRNA expression of FA transporters. mRNA expressions of genes were detected using qRT-PCR. Compared with the control group, ${ }^{* *}$ means $\mathrm{p}<0.01$

that is controlled by several proteins including: FATP, FABP and FAT (Stahl et al., 2001; Pohl et al., 2004; Stahl, 2004; Chabowski et al., 2006). Data obtained from the study showed that glucose markedly increased the mRNA expression levels of these transporters (Fig. 5). FATP1 and FAT showed similar changes in trend. With increasing glucose concentration, the mRNA expression of FATP1 and FAT in the cells significantly increased in the glucose-treated groups with the $15 \mathrm{mM}$ group showing the highest increase in FABP expression. Furthermore, the protein contents of the three transporters were determined using ELISA kits with results showing that the changes in protein contents were similar to changes at the gene level (Table 2).

\section{DISCUSSION}

Several studies in various species have provided increasing evidence that adipocyte differentiation is closely controlled by a variety of molecules (Ohyama et al., 1998; Ramsay and Rosebrough, 2003). Insulin, dexamethasone and 3-Isobutyl-1-Methylxanthine (IBMX) are most widely used to induce adipocyte differentiation in vitro and collectively called the adipocyte differentiation cocktail. One study found that fatty acids are essential inducers of chicken preadipocytes differentiation (Yoshiyuki et al., 2008). Several transcript regulatory factors or proteins have been considered as control factors for adipocyte differentiation. These master regulators include Sterol Regulatory Element-Binding Protein (SREBP), PPAR $\gamma, \mathrm{C} / \mathrm{EBP} \alpha$ and Adipocyte Fatty Acids-Binding Protein 2 (AP2 or FABP4) and express in different stages of adipocyte differentiation (Wagoner et al., 2006; Hansen et al., 1998).

Glucose is an important energy material for animal. Its concentration in medium was found to affect the function and metabolism of adipocytes in various species. A study found that increased glucose concentration result in stronger lipolysis in rat adipocytes (Szkudelski and Szkudelska, 2000). High concentrations of glucose were also found to cause the insulin resistance in 3T3-L1 preadipocytes (Wu et al., 2006). It has been reported glucose increased the expression level of visfatin in vitro. (Haider et al., 2006). However, the effect of glucose on avian cells remains unclear. In the current study, expression of $\mathrm{C} / \mathrm{EBP} \alpha$ and PPAR $\gamma$ both increased in high concentrations of glucose-treated cells and the results indicted that glucose in medium promote the differentiation of chicken preadipocytes in vitro. 
The mRNA expression and protein levels of FAS and ATGL as master regulators of fat metabolism were detected in this experiment. It is obvious that high glucose increased the FAS expression however, an increase of ATGL only appear in $25 \mathrm{mM}$ group. This result suggests that overhigh concentrations of glucose maybe promote lipolysis in chicken preadipocytes, similar to findings in mammalian cells. Moreover, the mRNA expression and protein contents of three FA transporters were markedly higher in glucose-treated cells than in control ones. This result indicates that fat metabolism is strengthened and more free fatty acids are released to flux adipocytes in/out. Changes observed in the transporters further indicate that they take different roles in the FA transport process.

\section{CONCLUSION}

This study shows that high concentrations of glucose in medium promote differentiation of chicken preadipocytes and overhigh concentration glucose maybe stimulates the lipolysis in the cells. Furthermore, the protein-mediated FFA transport system is more efficient in high glucose-treated preadipocytes than in low glucose- treated ones.

\section{REFERENCES}

Brun, R.P., J.B. Kim, E. Hu, S. Altiok andB.M. Spiegelman, 1996. Adipocyte differentiation: A transcriptional regulatory cascade. Curr. Opin. Cell Biol., 8: 826-832.

Chabowski, A., J.I. Gorsk and A. Bonen, 2006. Regulation of fatty acid transport: From transcriptional to posttranscriptional effects. Naunyn-Schmiedeberg's Arch. Pharmacol., 373: 259-263.

Fernyhough, M.E., E. Okine, G. Hausman, J.L. Vierck and M.V. Dodson, 2007. Invited review: PPAR-gamma and GLUT-4 expression as differentiation markers for preadipocyte conversion to become an adipocyte. Domest. Anim. Endocrinol., 33: 367-378.

Haider, D.G., G. Schaller and S. Kapiotis, 2006. The release of the adipocytokine visfatin is regulated by glucose and insulin. Diabetologia, 49: 1909-1914.

Hansen, L.H., B. Madsen, B. Teisner, J.H. Nielsen and N. Billestrup, 1998. Characterization of the inhibitory effect of growth hormone on primary preadipocyte differentiation. Mol. Endocrinal., 12: 1140-1149.

Lee, I., J. Yu, Y. Yoon, H.J. Gim and S.M. Lee et al., 2011. [5-(3-Indol-1-ylpropoxy)-1H-indol-3-yl] acetic acid enhances adipocyte differentiation and glucose uptake in 3T3-L1 cells. Int. J. Pharmacol., 7: 647-652.
Ohyama, M., K. Matsuda, S. Torii, T. Matsui and H. Yano et al., 1998. The interaction between vitamin $\mathrm{A}$ and thiazolidinedione on bovine adipocyte differentiation in primary culture. J. Anim. Sci., 76: 61-65.

Pohl, J., A. Ring, T. Hermaann and W. Stremmel, 2004. Role of FATP in parenchymal cell fatty acid uptake. Biochimica. Biophysica. Acta, 1686: 1-6.

Poulos, S.P., M.V. Dodson and G.J. Hausman, 2010. Cell line models for differentiation: Preadipocytes and adipocytes. Exp. Biol. Med., 235: 1185-1193.

Qiao, L.P., B. Lee, B. Kinney, H.S. Yoo and J.H. Shao, 2011. Energy intake and adiponectin gene expression. Am. J. Physiol. Endocrinol. Metab., 300: 809-816.

Ramsay, T.G. and R.W. Rosebrough, 2003. Hormonal regulation of postnatal chicken preadipocyte Differentiation in vitro. Comp. Bio. Physiol., 136: $245-253$.

Renaldi, O., B. Pramono, H. Sinorita, L.B. Purnomo, R.H. Asdie and A.H. Asdie, 2009. Hypoadiponectinemia: A risk factor for metabolic syndrome. Acta. Med. Indones., 41: 20-24.

Richards, M.P., M.P. Stephen, C.N. Coon, R. Rosebrough and R.W. Ashwell et al., 2003. Feed restriction signi?cantly alters lipogenic gene expression in broiler breeder chickens. J. Nutr., 133: 707-715.

Stahl, A., 2004. A current review of fatty acid transport proteins (SLC27). P?ugers. Arch., 447: 722-727.

Stahl, A., R.E. Gimeno, L.A. Tartagli and H.F. Lodish, 2001. Fatty acid transport proteins: A current view of a growing family. Trends Endocrinol. Metab., 12: 269-273.

Sun, C., R.L. Qi, L. Wang, J. Yan and Y. Wang, 2011b. P38 MAPK regulates calcium signal-mediated lipid accumulation through changing VDR expression in primary preadipocytes of mice. Mol. Biol. Rep., 10.1007/s11033-011-1084-8

Sun, C., Z.W. Wei and Y. Li, 2011a. DHA regulates lipogenesis and lipolysis genes in mice adipose and liver. Mol. Biol. Rep., 38: 731-737.

Szkudelski, T. and K. Szkudelska, 2000. Glucose as a lipolytic agent: Studies on isolated rat adiposities. Physiol. Res., 49: 213-217.

Tanaka, T., N. Yoshida, T. Kishimoto and S. Akira, 1997. Defective adipocyte differentiation in mice lacking the C/EBP beta and/or C/EBP delta gene. J., 16: 7432-7443.

Wagoner, B., D.B. Hausman and R.B. Harris, 2006. Direct and indirect effects of leptin on preadipocyte proliferation and differentiation. Am. J. Physiol. Regul. Integr. Comp. Physiol., 290: 1557-1564. 
Wu, H.R., S.G. Xiang, H.L. Lu and H.H. Lin, 2006. High Concentration glucose inducing insulin resistance in adipocytes. Acta. Med. Univ. Sci. Technol. Huazhong, 35: 66-68.

Yoshiyuki, M., E. Tsuyoshi and K. Koichiro, 2008. Fatty acids but not dexamethasone are essential inducers for chick adipocyte differentiation in vitro. Comp. Bio. Physiol., 151: 511-518.
Yuan, H. and C. Zhao, 2011. 3T3-L1 cell line revealing partially white adipogenesis of mice. Asian J. Anim. Vet. Adv., 6: 482-487.

Zhang, Y., R. Proenca, M. Maffei, M. Barone, L. Leopold and J.M. Friedman, 1994. Positional cloning of the mouse obese gene and its human homologue. Nature, 372: 425-432. 